\title{
Prerequisites for amplicon pyrosequencing of microbial methanol utilizers in the environment
}

\author{
Steffen Kolb* and Astrid Stacheter \\ Department of Ecological Microbiology, University of Bayreuth, Bayreuth, Germany
}

\section{Edited by:}

Marc Gregory Dumont, Max Planck Institute for Terrestrial Microbiology, Germany

\section{Reviewed by:}

Marina Kalyuzhnaya, University of Washington, USA

Svetlana N. Dedysh, Winogradsky Institute of Microbiology, Russian Academy of Sciences, Russia

\section{${ }^{*}$ Correspondence:}

Steffen Kolb, Department of Ecological Microbiology, University of Bayreuth, Dr.-Hans-Frisch-Str. 1-3, 95448 Bayreuth, Germany e-mail: steffen.kolb@uni-bayreuth.de
The commercial availability of next generation sequencing (NGS) technologies facilitated the assessment of functional groups of microorganisms in the environment with high coverage, resolution, and reproducibility. Soil methylotrophs were among the first microorganisms in the environment that were assessed with molecular tools, and nowadays, as well with NGS technologies. Studies in the past years re-attracted notice to the pivotal role of methylotrophs in global conversions of methanol, which mainly originates from plants, and is involved in oxidative reactions and ozone formation in the atmosphere. Aerobic methanol utilizers belong to Bacteria, yeasts, Ascomycota, and molds. Numerous bacterial methylotrophs are facultatively aerobic, and also contribute to anaerobic methanol oxidation in the environment, whereas strict anaerobic methanol utilizers belong to methanogens and acetogens. The diversity of enzymes catalyzing the initial oxidation of methanol is considerable, and comprises at least five different enzyme types in aerobes, and one in strict anaerobes. Only the gene of the large subunit of pyrroloquinoline quinone (PQQ)-dependent methanol dehydrogenase (MDH; $m \times a F)$ has been analyzed by environmental pyrosequencing. To enable a comprehensive assessment of methanol utilizers in the environment, new primers targeting genes of the PQQ MDH in Methylibium ( $m d h 2$ ), of the nicotinamide adenine dinucleotide-dependent $\mathrm{MDH}(\mathrm{mdh})$, of the methanol oxidoreductase of Actinobacteria (mdo), of the fungal flavin adenine nucleotide-dependent alcohol oxidase (mod1, mod2, and homologs), and of the gene of the large subunit of the methanol:corrinoid methyltransferases ( $m t a C)$ in methanogens and acetogens need to be developed. Combined stable isotope probing of nucleic acids or proteins with amplicon-based NGS are straightforward approaches to reveal insights into functions of certain methylotrophic taxa in the global methanol cycle.

Keywords: methylotroph, PQQ MDH, PQQ MDH2, NAD MDH, FAD AO, mtaC, xoxF, mxaF'

\section{PREFACE}

The commercial launch of pyrosequencing and later on, further next generation sequencing (NGS) technologies for direct sequencing of complex PCR amplicons facilitated the assessment of microbial communities by geno- and ribotype composition with high coverage and resolution, and with a high number of samples (e.g., Pilloni et al., 2012). Methylotrophic bacteria were among the first group of microorganisms that were analyzed by molecular tools in the environment (Holmes et al., 1995). Based on such studies substantially more is known on the pivotal role of microorganisms for global cycles of one-carbon (C1) compounds, such as the greenhouse gas methane. Another quantitatively important atmospheric volatile organic compound (VOC) is methanol. Nonetheless, in situ activities, environmental drivers, and distribution of methanol utilizers in the environment has scarcely been addressed (e.g., McDonald and Murrell, 1997), and just few years ago, studies re-attracted notice to activities of methanol utilizers in the environment (Delmotte et al., 2009; Dixon et al., 2011).

\section{METHYLOTROPHS IMPACT ON GLOBAL ONE-CARBON COMPOUND CYCLING}

Aerobic methylotrophs occur in terrestrial and aquatic environments on the whole planet, and have been detected in aerated and flooded soils of wetlands, grasslands, tundra, and deserts, and occur in the phyllosphere and rhizosphere of plants, in open ocean waters and other marine habitats (Giovannoni et al., 2008; Angel and Conrad, 2009; Kolb, 2009a; Wieczorek et al., 2011; Bissett et al., 2012; Gupta et al., 2012; He et al., 2012; Knief et al., 2012a; Vorholt, 2012) suggesting that their unique physiology that allows them to utilize reduced $\mathrm{C} 1$ compounds as carbon and energy source is of global relevance in ecosystems. Methylotrophs ubiquitously occur in terrestrial ecosystems, i.e., likely, since plants produce $\mathrm{C} 1$ compounds. Growing plants emit methanol (up to $0.1 \%$ of the photosynthetic carbon) and traces of chloromethane and methane (Keppler etal., 2005; Keppler et al., 2006), during decay of lignocellulosic plant material methanol is released (Galbally and Kirstine, 2002), and plant compounds are eventually converted to methane under anoxic conditions (Drake et al., 
2009). C1 compounds are highly volatile and thus, are emitted into the atmosphere. Consequently, the two most abundant organic compounds in the atmosphere are methane and methanol (Forster et al., 2007). The steady-state concentration of methanol in the atmosphere (1-10 ppb) is about 1,000-fold lower than that of atmospheric methane (1,800 ppb; Galbally and Kirstine, 2002; Heikes et al., 2002; Jacob et al., 2005). Whereas, the estimated global emission rate of methane $(\sim 10$ Tmol per year $)$ from terrestrial ecosystems is only twice as high as the global terrestrial emission rate of methanol ( $\sim 5$ Tmol per year) indicating that methanol is substantially more susceptible to atmospheric chemical reactions (Galbally and Kirstine, 2002; Jacob et al., 2005; Kolb, 2009a). Methanol triggers the formation of tropospheric ozone, and has indirectly a threefold higher global warming potential on a one-hundred-year basis than carbon dioxide (Forster et al., 2007).

Release of methane from terrestrial ecosystems into the atmosphere is reduced by aerobic methylotrophs (Conrad, 1995). Many aerated soils in natural ecosystems are even net sinks for atmospheric methane, which is often correlated with the predominance of certain genotypes, such as USC $\alpha$ (Dunfield, 2007; Kolb, 2009b). Methanotrophic methylotrophs have been addressed in numerous environmental studies by using gene markers and other biomarkers, and are one of the most studied functional groups of microorganisms in the environment (e.g., Dedysh, 2009; Kolb, 2009b; Dörr et al., 2010; Lüke et al., 2010; Lüke and Frenzel, 2011). There are more than 400 publications on methanotrophs in ecosystems over the past 25 years based on keyword searches in literature databases (Web of Knowledge, 04.07.2013, http://apps.webofknowledge.com) highlighting the interest in understanding the role of methanotrophs in the global carbon cycle.

Non-methanotrophic methylotrophs likely have a similar importance for the global methanol cycle, a fact that has recently been more thoroughly addressed in the phyllosphere, soil, and ocean waters (Delmotte et al., 2009; Kolb, 2009a; Knief etal., 2010a,b; Dixon et al., 2011, 2013; Vorholt, 2012; Stacheter et al., 2013). The assessment of methanol-utilizing methylotrophs in the environment is less straightforward than the detection of methanotrophs, since methanol utilizers have a substantially larger diversity than methanotrophs, and the enzymes that catalyze the diagnostic reaction, i.e., the oxidation of methanol to formaldehyde, are more diverse than methane monooxygenases making the detection of non-methanotrophic methanol utilizers more challenging (Chistoserdova et al., 2009; Kolb, 2009a; Stacheter et al., 2013).

The role of methanol utilizers in global methanol cycling is still scarcely investigated and warrants studies that address the response, activity, and distribution of methanol utilizers in terrestrial and other environments. Hence, suitable gene targets are mandatory to analyze methanol-utilizing microorganisms with amplicon pyrosequencing or to detect them in metagenomic, transcriptomic, and proteomic datasets based on sequence homology. The review will describe the latest knowledge on microbial taxa that are capable of methanol oxidation including those organisms that putatively utilize methanol under anoxic conditions, and will identify gene markers that have been and can be employed for analysis of PCR amplicons by high-throughput NGS techniques.

\section{FACULTATIVELY AEROBIC METHANOL UTILIZERS}

Microorganisms that have the capability to utilize methanol with molecular oxygen as an electron acceptor belong to various phyla of Bacteria, and have been found within yeast, mold fungi, and Ascomycota (Table 1; Bystrykh et al., 1988; Trotsenko and Bystrykh, 1990; Nakagawa et al., 1996; Nozaki et al., 1996; Silva et al., 2009; Sipiczki, 2012). Bacterial methanol utilizers belong to Alphaproteobacteria, Gammaproteobacteria, Betaproteobacteria, Flavobacteriia, Bacilli, and Actinobacteria. Yet, methanol utilization (MUT) among Archaea only occurs in strict anaerobic methanogens. Generally, it is known that several bacterial methylotrophs utilize methanol or other $\mathrm{C} 1$ compounds for dissimilation, but cannot assimilate carbon from C1 compounds. Strain HTCC2181 is a recent example, which demonstrates this strategy of C1 compound utilization (Giovannoni et al., 2008; Halsey et al., 2012). Over 200 aerobic species of methylotrophic Bacteria have been described (Tables 1 and 2; Kolb, 2009a). Most of the known isolates are Gram-negative. Thus, it is remarkable that a second isolate of the genus Bacillus has recently been described, which was not enriched on conventional methylotroph media suggesting a largely uncovered diversity of Gram-positive methanol utilizers in the environment (Table 2; Ling et al., 2011).

It is well established that some facultatively aerobic methanol utilizers are capable of growth on $\mathrm{C} 1$ compounds with nitrate as an electron acceptor (Kolb, 2009a). In addition, many more methylotrophs that have the ability to use nitrate as an alternative electron acceptor have not yet been tested for anaerobic methanol oxidation (Bamforth and Quayle, 1978; Kolb, 2009a); recent examples, in which the physiology has been thoroughly assessed, are Methyloversatilis universalis FAM5, and Methylotenera versatilis (Kalyuzhnaya et al., 2012; Lu etal., 2012; Mustakhimov et al., 2013). In environments with a high nitrogen input (for example by fertilization) and turnover, facultative aerobic and nitrate-dependent degradation of methanol likely occurs in oxygen-limited zones (Lu et al., 2012). Based on the current knowledge, these organisms are accessible by the same gene markers as described in the following section (Figure 1).

\section{MARKER GENES OF BACTERIAL METHANOL UTILIZERS}

Amplicon-based analysis of the diversity of methanol utilizers can be achieved by deep sequencing of genes that are diagnostic for methanol oxidation (Figure 1; Stacheter et al., 2013). The C1 metabolism of bacterial methanol utilizers comprises a series of enzymatic reactions, which partially cannot be found in other heterotrophs and are thus, diagnostic for methylotrophs. The most characteristic enzymatic step is the initial oxidation of methanol to formaldehyde (Figure 1). The oxidation of methanol can be catalyzed by at least three different enzymes in Bacteria. There is a pyrroloquinoline quinone (PQQ)-dependent and a nicotinamide adenine dinucleotide (NAD)-dependent methanol dehydrogenase $\mathrm{MDH}$; Devries etal., 1992; Chistoserdova et al., 2009; Krog et al., 2013). PQQ MDH occurs in Gram-negative Bacteria, whereas 
Table 1 | Classes and phyla of Bacteria and fungi that contain methanol-utilizing methylotrophs based on previous reviews (Kolb, 2009a; Gvozdev et al., 2012).

\begin{tabular}{|c|c|}
\hline Class/phylum/order & Representative species \\
\hline \multicolumn{2}{|l|}{ Actinobacteria } \\
\hline Brevibacteriaceae & Brevibacterium casei \\
\hline Micrococcaceae & Arthrobacter methylotrophus \\
\hline Mycobacteriaceae & Mycobacterium gastri \\
\hline Nocardiaceae & Rhodococcus erythropolis \\
\hline Pseudonocardiaceae & Amycolatopsis methanolica \\
\hline \multicolumn{2}{|l|}{ Bacilli } \\
\hline Bacillaceae & Bacillus methanolicus \\
\hline \multicolumn{2}{|l|}{ Alphaproteobacteria } \\
\hline Acetobacteraceae & Acidomonas methanolica \\
\hline Beijerinckiaceae & Methylocapsa aurea \\
\hline Bradyrhizobiaceae & Afipia felis \\
\hline Hyphomicrobiaceae & Angulomicrobium tetraedrale \\
\hline Methylobacteriaceae & Methylobacterium extorquens \\
\hline Methylocystaceae & Methlyopila jiangsuensis \\
\hline Phyllobacteriaceae & Mesorhizobium lotiA \\
\hline Rhizobiaceae & Ensifer fredii ${ }^{\mathrm{A}}$ \\
\hline Rhodobacteraceae & Paracoccus alkenifer \\
\hline Sphingomonadaceae & Sphingomonas melonis \\
\hline Xanthobacteraceae & Ancylobacter dichloromethanicus \\
\hline \multicolumn{2}{|l|}{ Betaproteobacteria } \\
\hline Comomonadaceae & Variovorax paradoxus \\
\hline Methylophilaceae & Methylophilus glucosoxydans \\
\hline Rhodocyclaceae & Methyloversatilis universalis \\
\hline Burkholderiales & Methylibium aquaticum \\
\hline \multicolumn{2}{|l|}{ Gammaproteobacteria } \\
\hline Enterobacteriaceae & Klebsiella oxytoca \\
\hline Methylococcaceae & Methylococcus capsulatus \\
\hline Piscirickettsiaceae & Methylophaga thiooxydans \\
\hline Vibrionaceae & Photobacterium indicum \\
\hline Classification unclear & Methylohalomonas lacus \\
\hline \multicolumn{2}{|l|}{ Ascomycota } \\
\hline & Gliocladium deliquescens \\
\hline & Paecilomyces variotii \\
\hline & Trichoderma lignorum \\
\hline \multicolumn{2}{|l|}{ Yeasts } \\
\hline & Candida boidini (and others) \\
\hline & Hansenula capsulatus (and others) \\
\hline & Pichia pastoris (and others) \\
\hline \multicolumn{2}{|l|}{ Mold fungi } \\
\hline & Paecilomyces variotii \\
\hline & Penicillium chrysogenum \\
\hline
\end{tabular}

A Harbors xoxF-like gene mxaF. Growth on methanol has not been tested. the NAD MDH is typical of Gram-positive Bacillus strains and is encoded by the gene mdh (Chistoserdova et al., 2009). Furthermore, in Gram-positive Actinobacteria (Amycolatopsis methanolica, Mycobacterium gastri MB19) a methanol:NDMA $\left(N, N^{\prime}\right.$-dimethyl-4-nitrosoaniline) oxidoreductase (MDO) has been reported (Bystrykh et al., 1993; Vanophem et al., 1993; Park et al., 2010).

The gene mxaF encodes the catalytic subunit of PQQ MDH, which is composed of two different subunits (i.e., MxaFI). However, there is a distantly related homolog in some methylotrophic Burkholderiales (Methylibium; i.e., the gene was named $m d h 2$ ), which encodes an alternative PQQ-dependent $\mathrm{MDH}$ (Kalyuzhnaya et al., 2008). Beyond $m d h 2$, a further homolog of $m x a F$ is known, i.e., $x o x F$, for which a functional role in methanolmetabolism is under debate. $x o x F$-like genes (synonymous to $m x a F^{\prime}$ ) occur in Bradyrhizobiaceae and other rhizobia, and may encode functional MDHs (Fitriyanto et al., 2011). Similar genes can be frequently detected in soil microbial communities using mxaF-specific primers (Table 1; Stacheter et al., 2013). If rhizobia that do not possess the classical PQQ MDH (i.e., MxaFI; Moosvi etal., 2005), also utilize and grow on methanol has not systematically been analyzed yet. Nonetheless, Bradyrhizobium sp. MAFF211645 contains a $\mathrm{Ce}^{3+}$-inducible XoxF-like MDH (Fitriyanto et al., 2011). The first functional proof of XoxF as a $\mathrm{MDH}$ was demonstrated in the phototroph Rhodobacter sphaeroides (Wilson et al., 2008). Studies on Methylobacterium extorquens AM1 suggest that XoxF1 and XoxF2 are involved in the regulation of mxaF (Schmidt et al., 2010; Skovran et al., 2011). Purified XoxF1 of Methylobacterium extorquens AM1 has highest methanol oxidation activities when cells were grown with methanol and $30 \mu \mathrm{M} \mathrm{La}^{3+}$. These activities were comparable to the canonical PQQ MDH MxaFI. The purified XoxF enzyme contained $\mathrm{La}^{3+}$ suggesting that XoxF is important as a calcium-independent MDH that uses rare earth elements as cofactors (Nakagawa et al., 2012). In recently discovered methanotrophs of the phylum Verrucomicrobia, xoxF is the only detectable gene that may code for MDH (Op den Camp etal., 2009). xoxF also occurs in non-methylotrophic bacteria, in which its metabolic function is unresolved (Chistoserdova, 2011). Thus, the detection of $x o x F$ by NGS in environmental gene surveys or their occurrence in metagenomes, transcriptomes, and proteomes may be a hint to environmental methanol oxidation but need to be carefully evaluated based on recent and upcoming results from pure cultures of various organisms.

A comprehensive assessment of the genotypic diversity of aerobic methanol utilizers in the environment seems possible when $m x a F, x o x F-$-like, $m d h 2, m d h$, and genes of MDO of Actinobacteria are simultaneously analyzed. However, only $m x a F$ has been successfully detected to date and PCR primers suitable for environmental surveys of the other genes have not yet been developed (McDonald and Murrell, 1997; Neufeld et al., 2007; Stacheter et al., 2013). More studies on the function of $x o x F$ in further methylotrophs and addressing the physiological role of xoxF in organisms that are currently not known as methylotrophs are warranted to improve the ability to interprete methylotrophy gene-targeting surveys in the environment. The employment of 
Table 2 | List of methanol-utilizing methylotophs that are not included in a previous survey (Kolb, 2009a).

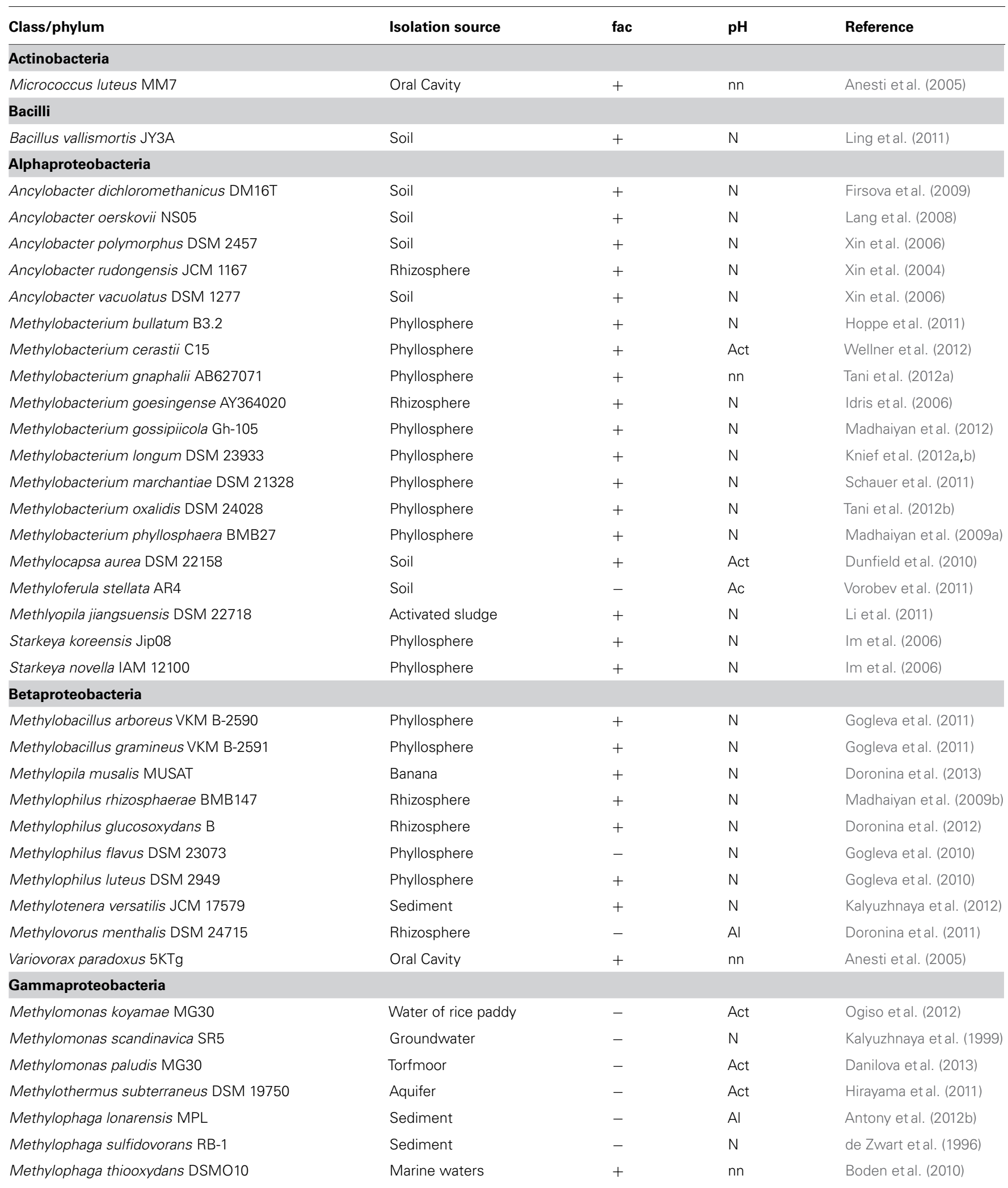

fac, facultative methylotrophic; +, growth in substrates with carbon-carbon bonds; -, no growth in substrates with carbon-carbon bonds; nn, no information in species description; enrichment at pH 7; N, neutrophile (growth optimum between pH 6.5 and 8.0); Act, acid tolerant (growth optimum between pH 3.0 und 6.5); Ac, acidiphilic (growth optimum below pH 3); Al, alcaliphilic (growth optimum over pH 8). 


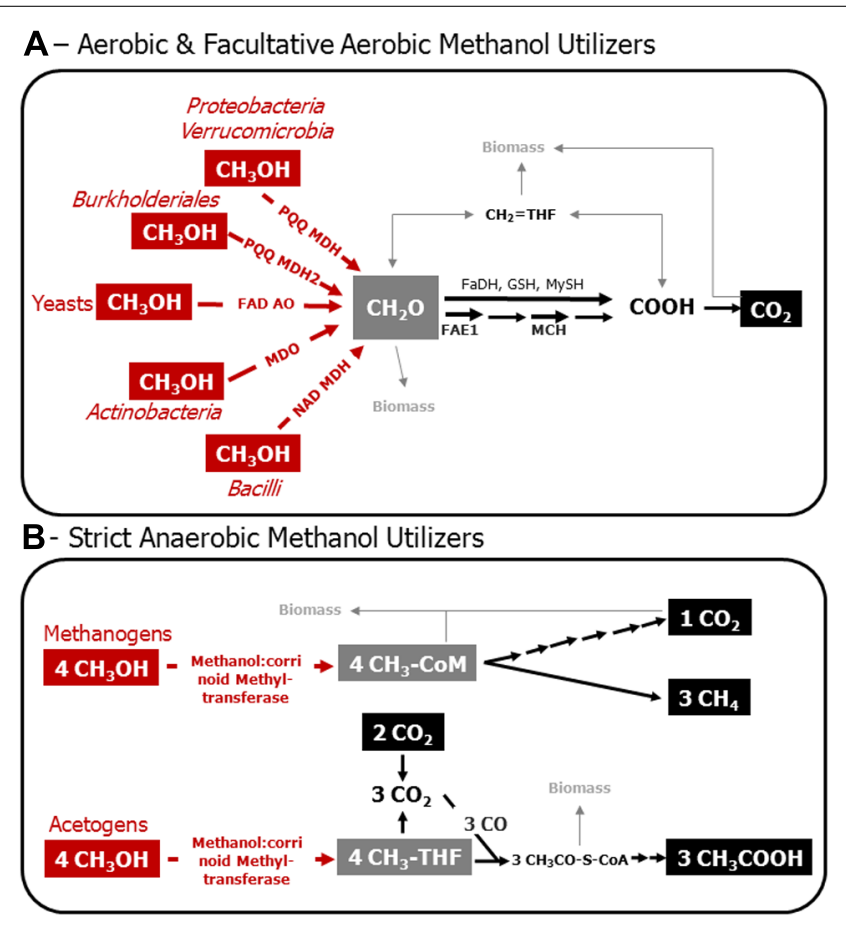

FIGURE 1 | Model of the C1 metabolism of aerobic and facultatively aerobic methanol utilizers (A), and of methanol-utilizing methanogens and acetogens (B). Various Bacteria that employ $\mathrm{PQQ} \mathrm{MDH}$ and $\mathrm{PQQ}$ $\mathrm{MDH} 2$ utilize nitrate besides molecular oxygen, and are, thus, facultative aerobes. Red, enzymatic reactions indicative for methanol utilization. Gray, metabolic crossing points to anabolic pathways. Structural genes are targets for the molecular assessment of methanol-utilizing microorganisms in the environment. $\mathrm{PQQ} \mathrm{MDH}, \mathrm{PQQ}$-dependent methanol dehydrogenase; PQQ MDH2, alternative PQQ-dependent methanol dehydrogenase in Methylibium andBurkholderia strains; FAD AO, FAD-dependent alcohol oxidoreductase; MDO, methanol oxidoreductase; NAD MDH, NAD-dependent methanol dehydrogenase; FAE1,

tetrahydromethanopterin-dependent formaldehyde activating enzyme; $\mathrm{MCH}$, tetrahydromethanopterin-dependent methenyl-methylene cyclohydrolase; FaDH, formaldehyde dehydrogenase; $\mathrm{GSH}$, glutathione-dependent formaldehyde oxidation; $\mathrm{MySH}$, mycothiol-dependent oxidation of formaldehyde in yeast; $\mathrm{CH}_{2}=\mathrm{HF} 4$, methylene tetrahydrofolate; $\mathrm{CH}_{3}-\mathrm{THF}$, methyl-tetrahydrofolate; $\mathrm{CH}_{3}-\mathrm{CoM}$, methyl-coenzyme $\mathrm{M} ; \mathrm{CH}_{3} \mathrm{OH}$, methanol; $\mathrm{CH}_{2} \mathrm{O}$, formaldehyde; $\mathrm{COOH}$ formate; $\mathrm{CO}_{2}$, carbon dioxide; $\mathrm{CO}$, carbon monoxide; $\mathrm{CH}_{3} \mathrm{CO}-\mathrm{S}-\mathrm{CoA}$, acetyl coenzyme $\mathrm{A} ; \mathrm{CH}_{3} \mathrm{COOH}$, acetic acid. Biomass, assimilation of carbon occurs at the level of formaldehyde and/or on carbon dioxide in aerobic methylotrophs; pathways involved are the Calvin-Benson-Bassham cycle, ribulose-monophosphate pathway, and the serine cycle. Assimilation of carbon in methanogens is mediated by a unique reductive acetyl-CoA-pathway, whereas acetogens form acetyl-CoA as an intermediate that can be used for biosnthesis. This figure is based on previous articles (Thauer, 1998; Ding et al., 2002; Hagemeier et al., 2006; Das et al., 2007; Drake et al., 2008; Chistoserdova et al., 2009;

Chistoserdova, 2011; Gvozdev et al., 2012).

genes of MDHs of Gram-positive methylotrophs will enhance the environmental detectability of methanol utilizers and will aid to understand the role of these largely overlooked methylotrophs for methanol conversion in ecosystems.

In addition to gene markers that are diagnostic for methanol oxidation, the genes mch (methenyl:methylene tetrahydromethanopterin cyclohydrolase) and fae 1 (formaldehyde- activating enzyme) that are indicative for dissimilatory oxidation of formaldehyde by tetrahydromethanopterin-dependent reactions have been used to detect methylotrophs in the environment (Kalyuzhnaya et al., 2004; Kalyuzhnaya and Chistoserdova, 2005; Stacheter et al., 2013; Table 3). However, their detection alone does not allow for the conclusion that the detected organisms are methanol utilizers since fae 1 and $m c h$ also occur in non-methylotrophic heterotrophs (Chistoserdova, 2011; Stacheter et al., 2013).

\section{ROUTES TOWARD ENVIRONMENTAL DETECTION OF METHYLOTROPHIC YEASTS, MOLDS, AND ASCOMYCOTA}

Fungi employ a unique pathway for methanol oxidation, in which methanol is oxidized via formaldehyde and formate to carbon dioxide, i.e., the MUT pathway (Hartner and Glieder, 2006; Figure 1). The initial oxidation of methanol is mediated by a flavin adenine nucleotide (FAD) dependent alcohol oxidase (FAD AO) that produces formaldehyde and hydrogen peroxide (Hartner and Glieder, 2006). FAD AO occurs in various genera of yeasts, such as Candida and Pichia, in molds, and Ascomycota (Table 1; Vandenbosch et al., 1992; Gvozdev et al., 2012). Known genes encoding for FAD AOs are mod1 and $\bmod 2$, however homologs exist of which the function is unresolved (Nakagawa et al., 2006; Gvozdev et al., 2012). The use of genes of FAD AO for the environmental detection of methylotrophic fungi will be still challenging since numerous isoenzymes with likely different kinetic properties exist (Table 1; Ito et al., 2007). The role of the diversity and activity of fungal microorganisms for environmental conversion of methanol has scarcely been studied (Table 1), and warrants, especially in terrestrial environments, future research.

\section{POTENTIAL GENE MARKERS OF STRICT ANAEROBIC METHANOL UTILIZERS}

The quantitative contribution of anaerobic methanol conversion in soils has scarcely been analyzed (Conrad and Claus, 2005). Beyond facultative aerobic methylotrophs, some strict anaerobes utilize methanol, i.e., methylotrophic methanogens and acetogens. A methanol-utilizing acetogen is Moorella thermoacetica, and examples for methanol-utilizing methanogens are Methanosarcina acetivorans, Methanolobus sp., and Methanosarcina barkeri (Das etal., 2007; Antony et al., 2012a; Penger etal., 2012). Recently, the methanol-oxidizing enzyme methanol:corrinoid methyltransferase $(\mathrm{MtaC})$, encoded by $m t a C$, has been structurally characterized in these organisms (Ding et al., 2002; Hagemeier et al., 2006). An enzyme with homology to MtaC is upregulated during growth on methanol in methylotrophic acetogens (Zhou etal., 2005; Das etal., 2007). Hence, the gene mtaC and its homolog in acetogens are promising targets to develop genebased detection of strict anaerobic methanol utilizers in the environment.

\section{ASSESSMENT OF METHANOL UTILIZERS BY AMPLICON PYROSEQUENCING}

The advent of NGS technologies allow for a dramatic increase of sequence information compared with similar efforts when using classic Sanger sequencing (Christen, 2008; Liu et al., 2012). 
Table 3 | Gene markers of methanol-utilizing microorganisms for amplicon-based pyrosequencing or as targets for homology screens in metagenome, -trancriptome, or -proteome datasets.

\begin{tabular}{|c|c|c|c|c|c|c|}
\hline Methanol utilizers & Enzyme & Function & Gene marker & Primers & Reference & Pyroseq $^{D}$ \\
\hline Proteobacteria & $\mathrm{PQO} \mathrm{MDH}$ & $\mathrm{MeOH}$ ox. & $m \times a F$ & $1003 f / 1555 r^{E}$ & $\begin{array}{l}\text { McDonald and Murrell (1997); } \\
\text { Neufeld et al. (2007) }\end{array}$ & Yes \\
\hline $\begin{array}{l}\text { Proteobacteria, } \\
\text { Verrucomicrobia }\end{array}$ & $\mathrm{PQQ} \mathrm{MDH}$ & $\begin{array}{l}\text { Putatively } \\
\mathrm{MeOH} \text { ox. }\end{array}$ & xoxF & $1003 f / 1555 r^{E}$ & $\begin{array}{l}\text { McDonald and Murrell (1997); } \\
\text { Neufeld etal. (2007) }\end{array}$ & Yes \\
\hline Burkholderiales & PQO MDH2 & $\mathrm{MeOH}$ ox. & $m d h 2$ & Not available $\mathrm{A}^{\mathrm{A}}$ & Kalyuzhnaya et al. (2008) & No \\
\hline & $\mathrm{MCH}$ & Other ${ }^{B}$ & mch & mch-2a/mch-3 & $\begin{array}{l}\text { Vorholt et al. (1999); Kalyuzhnaya } \\
\text { and Chistoserdova (2005) }\end{array}$ & Yes \\
\hline Actinobacteria & MDO & $\mathrm{MeOH}$ ox. & mdo & Not available ${ }^{A}$ & Park et al. (2010) & No \\
\hline Bacilli & $\mathrm{NAD} \mathrm{MDH}$ & $\mathrm{MeOH}$ ox. & $m d h$ & Not available $\mathrm{A}^{\mathrm{A}}$ & $\begin{array}{l}\text { Devries etal. (1992); Krog etal. } \\
\text { (2013) }\end{array}$ & No \\
\hline Methylotrophic acetogens & $\begin{array}{l}\text { Methanol:CoM } \\
\text { methyl-transferase } \\
\text { system-like }\end{array}$ & $\mathrm{MeOH}$ ox. & $m t a C$-like ${ }^{C}$ & Not available $\mathrm{A}^{\mathrm{A}}$ & Das et al. (2007) & No \\
\hline Fungi & FAD AO & $\mathrm{MeOH}$ ox. & $\begin{array}{l}\bmod 1, \bmod 2, \\
\text { others }\end{array}$ & Not available ${ }^{A}$ & $\begin{array}{l}\text { Reid and Fewson (1994); Ozimek } \\
\text { etal. (2005), Hartner and Glieder } \\
\text { (2006); Nakagawa etal. (2006) }\end{array}$ & No \\
\hline
\end{tabular}

$\mathrm{MeOH}$, methanol oxidation.

A Primers for this group of genes have not designed and tested in environmental surveys.

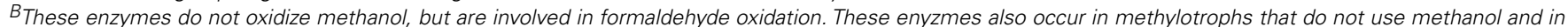
non-methylotrophs (Chistoserdova, 2011).

C Homologs of unknown function are present in methanogens (Ding etal., 2002).

DHas been used in amplicon pyrosequencing.

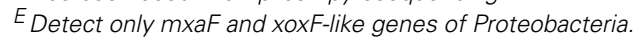

Amplicon pyrosequencing (i.e., a synonymous term is pyrotag sequencing) is one of the best evaluated and oldest NGS technologies (Liu et al., 2012). Long reads of about 700-1000 bp are possible, and technically unavoidable sequence errors can be removed with established software, such as AmpliconNoise (Quince etal., 2011; Rosen etal., 2012). Thus, large datasets with over 100,000 reads can be quality filtered, trimmed, sorted, and clustered into sequence similarity-defined operational taxonomic units (Caporaso etal., 2010; Nebel et al., 2011). Amplicon pyrosequencing comes along with higher costs per read compared to cheaper technologies, such as HiSeq, MiSeq, or Ion Torrent (Liu et al., 2012). However, the long-read length of pyrosequencing is especially advantageous when analyzing amplicons. Beyond that, ampliconbased pyrosequencing generates highly reproducible and similar community structures when compared to standard community fingerprinting techniques, such as terminal restriction fragment length polymorphism (TRFLP) analysis and thus, can be used for reliable genotype composition analyses (Pilloni et al., 2012).
Amplicons can be obtained with primers that contain adapter sequences that are needed for emulsion PCR-based amplification to generate nanobead-bound sequence libraries (Ronaghi et al., 1998). Usually such primers include a several nucleotidelong sequence for the identification of the source of sequence (i.e., a barcode), such as an individual sample within the study (Pilloni et al., 2012). A consequence is long primers with unspecific extensions at $5^{\prime}$ end. This may lead to reduced sensitivity of amplification and to unspecific binding (Berry et al., 2011). One strategy to overcome this bias is applying two subsequent PCRs. The first PCR is conducted with untagged primers followed by a second PCR with tagged primers (Berry et al., 2011). An alternative strategy to minimize these shortcomings is to use primers with barcodes, but without adapter sequences. Adapters need to be added by ligation after the PCR (Stacheter et al., 2013). A complication of such an approach is the retrieval of two datasets one with sequences starting with forward and one starting with the reverse primer, but minimizes bias during amplicon amplification (Stacheter et al., 2013). Environmental detection of mxaF-like genotypes of methylotrophs by primers $1003 \mathrm{f}$ and $1555 \mathrm{r}$ include 
the detection of xoxF-like genes (Table 3; Stacheter et al., 2013). When $m x a F$-targeting primers were used, also xoxF-like genes were detected in various grassland and forest soils by amplicon pyrosequencing (Stacheter et al., 2013) making the interpretation of data in regard to the capability of detected microorganisms of methanol oxidation more difficult, since the function of $x o x F$ is still in part under debate.

\section{mxaF AND HOMOLOGS FOR ENVIRONMENTAL DETECTION OF METHYLOTROPHS}

Analysis of non-methanotrophic methylotrophs by mxaF genotyping has been employed in several studies. Nonetheless, only one study exist that employed amplicon pyrosequencing (Table 4). All other amplicon-based NGS studies addressed methanotrophs and mostly analyzed pmoA (i.e., encodes a gene of a subunit of the particulate methane monooxygenase). The use of amplicon pyrosequencing is a great step forward toward complete coverage of the real diversity that exists in a given habitat. In this review, the authors argue in favor to target structural genes of methanol utilizers. One advantage of the use of structural genes is the increased sensitivity since rare groups, such as methylotrophs in soil communities, can be more reliably detected than by a $16 \mathrm{~S}$ rRNA gene-based survey. Several methylotrophs occur in taxa of which only some members are capable of methylotrophy (e.g., Bacillaceae; Tables 1 and 2). The detection of such methylotrophs by $16 \mathrm{~S}$ rRNA genes can be misleading, and thus, another advantage of the use of genes encoding a methanoloxidizing enzyme is that the detection of the gene marker is linked with the potential phenotype of MUT. Nonetheless, gene marker-based phylogenies are not always congruent with organismal phylogenies (i.e., due to horizontal gene exchange between distantly related bacteria or evolution of functionally slightly different enzymes in the same organism; Friedrich, 2002). In general, mxaF-based phylogenies correlate with organismal phylogenies on the level of families of methylotrophs (Kist and Tate, 2013a,b; Lau et al., 2013). However, for other genes ( $\operatorname{mdh} 2, \operatorname{mdo}$, mdh, mod1, $\bmod 2, m t a C)$ of methanol-oxidizing enzymes, congruence with organismal phylogenies needs to be evaluated.

Recent evaluation of phylogenetic resolution of $m x a F$ compared to organismal phylogenies revealed contradicting results (Kist and Tate, 2013a,b; Lau et al., 2013). The congruency with the $16 \mathrm{~S}$ rRNA gene phylogeny and the resolution of $m x a F$ is sufficient (except for some "anomalies") in the non-methanotrophic genus Methylobacterium (affiliates with Alphaproteobacteria), i.e., the so-called pink-pigmented, facultatively methylotrophic (PPFM) bacteria (Kist and Tate, 2013a,b), and mxaF-based taxonomic resolution might be even higher than that of $16 \mathrm{~S}$ rRNA genes (Kist and Tate, 2013b). Nonetheless, strain-level identification is not possible and requires the analysis of more variable genomic regions (Knief et al., 2008, 2010b). Some alphaproteobacterial genera harbor mxaF-like genes that are similar to those of Methylobacterium suggesting the occurrence horizontal gene transfer events in evolution of methylotrophs; Methylobacterium nodulans ORS 2060A carries a plasmid with methylotrophy genes including mxaF, suggesting that this species has acquired this gene from another PPFM bacterium (Kist and Tate, 2013a). Using $m x a F$ as a phylogenetic marker of methanotrophic Proteobacteria revealed that the three major families Methylococcaceae, Methylocystaceae, and Beijerinckiaceae can be unambiguously reconstructed (Lau et al., 2013). Nonetheless, mxaF and 16S rRNA gene phylogenies differ on genus and species level (Lau et al., 2013). The loose coupling of mxaF phylogenies with $16 \mathrm{~S}$ rRNA gene phylogenies is reflected by a low DNA-level similarity (about 77\%) that relates to a 97\% similarity cut-off on $16 \mathrm{~S}$ rRNA gene sequence level, which is indicative for species. This low mxaF cut-off level even decreases when more species are considered (Stacheter et al., 2013) supporting the conclusion that horizontal gene transfer occurred between methylotrophs and non-methylotrophs. A frequently detected

Table 4 | Use of amplicon pyrosequencing to analyze methylotrophic communities.

\begin{tabular}{|c|c|c|c|c|}
\hline Environment & Gene markers & Remarks & Functional group & Reference \\
\hline \multicolumn{5}{|l|}{ Soils } \\
\hline Aerated soils & $m x a F$, mch, fae 1 & $\begin{array}{l}\text { Amplification with adapter-less } \\
\text { primers }\end{array}$ & Bacterial methylotrophs & Stacheter et al. (2013) \\
\hline Hydromorphic grassland soil & pmoA & - & Methanotrophs & Shrestha et al. (2012) \\
\hline Peatland & pmoA & & Methanotrophs & Deng etal. (2013) \\
\hline Paddy soils & pmoA & - & Methanotrophs & Lüke and Frenzel (2011) \\
\hline Peat bog & pmoA & $\begin{array}{l}\text { Read length }>500 \mathrm{nt} \text {, blended } \\
\text { analysis with other genes }\end{array}$ & Methanotrophs & Kip et al. (2011) \\
\hline \multicolumn{5}{|l|}{ Aquatic habitats } \\
\hline Lake sediments and waters & $16 \mathrm{~S}$ rRNA genes & Combined with DNA SIP & Methanotrophs & He etal. (2012) \\
\hline Water of oil sand tailings ponds & pmoA & - & Methanotrophs & Saidi-Mehrabad et al. (2013) \\
\hline \multicolumn{5}{|l|}{ Aquifer } \\
\hline Aquifer & 16S rRNA genes & V4-V6 region of $16 \mathrm{~S}$ rRNA & Methylotrophs (and others) & Lavalleur and Colwell (2013) \\
\hline \multicolumn{5}{|l|}{ Technical systems } \\
\hline Methanotrophic biofilter & $16 \mathrm{~S}$ rRNA genes & - & Methanotrophs (and others) & Kim et al. (2013) \\
\hline
\end{tabular}


$m x a F$ genotype in temperate aerated soils is closely related to the methanotroph Methyloferula stellata AR4. Nonetheless, due to lack of congruencies between mxaF and 16S rRNA gene phylogenies in Beijerinckiaceae, it cannot be judged if this mxaF genotype was derived from a methanotroph or a non-methanotrophic methylotroph (Lau etal., 2013; Stacheter et al., 2013). Thus, a more in-depth analysis of bacteria that harbor MxaFI-, XoxF-, and Mdh2-like MDHs on the level of genomes is warranted to improve the understanding of the role of horizontal gene transfer and convergences in these organisms aiming at a more correct interpretation of $m x a F, x o x F$-like, and mdh2 datasets retrieved from amplicon-based NGS.

\section{FUTURE PERSPECTIVES}

In the era of metagenomics, -transcriptomics, and -proteomics, it is noteworthy to state that the knowledge on diversities of methanol-oxidizing enzymes will also facilitate the detection of such organisms and their metabolic pathways in "omic" datasets. An example is the detection of an actinobacterial MDO-like protein in a metaproteome of rice plants (Knief et al., 2012a). Since the Mdh2 or fungal MDOs have a broad substrate spectrum and may utilize alternative substrates (Nakagawa et al., 2006;

\section{REFERENCES}

Anesti, V., Mcdonald, I. R., Ramaswamy, M., Wade, W. G., Kelly, D. P., and Wood, A. P. (2005). Isolation and molecular detection of methylotrophic bacteria occurring in the human mouth. Environ. Microbiol. 7, 1227-1238. doi: $10.1111 / \mathrm{j} .1462$ 2920.2005.00805.x

Angel, R., and Conrad, R. (2009). In situ measurement of methane fluxes and analysis of transcribed particulate methane monooxygenase in desert soils. Environ. Microbiol. 11, 2598-2610. doi: 10.1111/j.14622920.2009.01984.x

Antony, C. P., Kumaresan, D., Ferrando, L., Boden, R., Moussard, H., Scavino, A. F., et al. (2010). Active methylotrophs in the sediments of Lonar Lake, a saline and alkaline ecosystem formed by meteor impact. ISME J. 4, 1470-1480 doi: 10.1038/ismej.2010.70

Antony, C. P., Murrell, J. C., and Shouche, Y. S. (2012a). Molecular diversity of methanogens and identification of Methanolobus sp. as active methylotrophic Archaea in Lonar crater lake sediments. FEMS Microbiol. Ecol. 81, 43-51 doi: 10.1111/j.1574-6941.2011.01274.x

Antony, C. P., Doronina, N. V., Boden, R., Trotsenko, Y. A., Shouche, Y. S., and Murrell, J. C. (2012b). Methylophaga lonarensis sp. nov., a moderately haloalkaliphilic methylotroph isolated from the soda lake sediments of a meteorite impact crater. Int. J. Syst. Evol. Microbiol. 62, 1613-1618. doi: 10.1099/ijs.0.035089-0
Bamforth, C. W., and Quayle, J. R. (1978). Aerobic and anaerobic growth of Paracoccus denitrificans on methanol. Arch. Microbiol. 119, 91-97. doi: 10.1007/BF0040 7934

Berry, D., Ben Mahfoudh, K., Wagner, M., and Loy, A. (2011). Barcoded primers used in multiplex amplicon pyrosequencing bias amplification. Appl. Environ. Microbiol. 77, 7846-7849. doi: 10.1128/AEM. 05220-11

Bissett, A., Abell, G. C. J., Bodrossy, L., Richardson, A. E., and Thrall, P. H. (2012). Methanotrophic communities in Australian woodland soils of varying salinity. FEMS Microbiol. Ecol. 80, 685-695. doi: $\quad 10.1111 / \mathrm{j} .1574-6941.2012$ 01341.x

Boden, R., Kelly, D. P., Murrell, J. C., and Schäfer, H. (2010). Oxidation of dimethylsulfide to tetrathionate by Methylophaga thiooxidans sp. nov: a new link in the sulfur cycle. Environ. Microbiol. 12, 2688 2699. doi: 10.1111/j.1462-2920.2010. 02238.x

Bystrykh, L. V., Aminova, L. R., and Trotsenko, Y. A. (1988). Methanol metabolism in mutants of the methylotrophic yeast Hansenula polymorpha. FEMS Microbiol. Lett. 51, 89-93. doi: 10.1111/j.15746968.1988.tb02975.x

Bystrykh, L. V., Vonck, J., Vanbruggen, E. F. J., Vanbeeumen, J., Samyn, B., Govorukhina, N. I., et al. (1993). Electron-microscopic analysis and structural characterization

Kalyuzhnaya et al., 2008; Gvozdev etal., 2012), their role in in situ methanol-oxidation based solely on the detection of their genes is ambiguous when their activity dependent on methanol in situ cannot be demonstrated. Moreover, many methylotrophs are capable of utilization of multicarbon compounds. Thus, the detection of a genotype does not necessarily mean that the respective microorganism was involved in methanol oxidation in situ. Hence, approaches combining gene marker-based nucleic acid stable isotope probing (SIP; Antony et al., 2010) or even together with protein SIP (Jehmlich et al., 2010) are promising to detect active methanol utilizers in terrestrial and other environments, and may allow for detection of novel oxidoreductases and microorganisms that utilize methanol in the environment. Still not resolved issues for a comprehensive detection of methanol utilizers are (a) the unresolved quantitative impact of organisms that employ other methanol-oxidizing enzymes than methanol-specific oxidoreductases, and (b) the detection of methanol utilizers that dissimilate but do not assimilate methanol-derived carbon. Such organisms might be detectable by SIP when using their actual carbon substrate as a source of isotope label combined with unlabeled methanol and a control, in which the labeled substrate is not supplemented.

of novel $\mathrm{NADP}(\mathrm{H})$-containing methanol - N, $N^{\prime}$-dimethyl-4nitrosoaniline oxidoreductases from the Gram-positive methylotrophic bacteria Amycolatopsis methanolica and Mycobacterium gastri Mb19. J. Bacteriol. 175, 1814-1822.

Caporaso, J. G., Kuczynski, J., Stombaugh, J., Bittinger, K., Bushman, F. D., Costello, E. K., et al. (2010). QIIME allows analysis of high-throughput community sequencing data. Nat. Methods 7, 335-336. doi: 10.1038/ nmeth.f.303

Chistoserdova, L. (2011). Modularity of methylotrophy, revisited. Environ. Microbiol. 13, 26032622. doi: 10.1111/j.1462-2920.2011. 02464.x

Chistoserdova, L., Kalyuzhnaya, M. G., and Lidstrom, M. E. (2009). The expanding world of methylotrophic metabolism. Annu. Rev. Microbiol. 63, 477-499. doi: 10.1146/ annurev.micro.091208.073600

Christen, R. (2008). Global sequencing: a review of current molecular data and new methods available to assess microbial diversity. Microbes Environ. 23, 253-268. doi 10.1264/jsme2.ME08525

Conrad, R. (1995). Soil microbial processes involved in production and consumption of atmospheric trace gases. Adv. Microb. Ecol. 14 207-250. doi: 10.1007/978-1-46847724-5_5

Conrad, R., and Claus, P. (2005). Contribution of methanol to the production of methane and its $\mathrm{C}$-13-isotopic signature in anoxic rice field soil. Biogeochemistry 73, 381-393. doi: 10.1007/s10533-004-0366-9

Danilova, O. V., Kulichevskaya, I. S., Rozova, O. N., Detkova, E. N., Bodelier, P. L., Trotsenko, Y. A., et al. (2013). Methylomonas paludis sp. nov., the first acid-tolerant member of the genus Methylomonas, from an acidic wetland. Int. J. Syst. Evol. Microbiol. 63, 2282-2289. doi: 10.1099/ijs.0.045658-0

Das, A., Fu, Z. Q., Tempel, W., Liu, Z. J., Chang, J., Chen, L. R., et al. (2007). Characterization of a corrinoid protein involved in the $\mathrm{Cl}$ metabolism of strict anaerobic bacterium Moorella thermoacetica. Proteins 67, 167-176. doi: 10.1002/prot.21094

Dedysh, S. N. (2009). Exploring methanotroph diversity in acidic northern wetlands: molecular and cultivation-based studies. Microbiology 78, 655-669. doi: $10.1134 / \mathrm{S} 0026261709060010$

Delmotte, N., Knief, C., Chaffron, S., Innerebner, G., Roschitzki, B., Schlapbach, R., et al. (2009). Community proteogenomics reveals insights into the physiology of phyllosphere bacteria. Proc. Natl. Acad. Sci. U.S.A. 106, 16428-16433. doi: 10.1073/pnas.0905240106

Deng, Y., Cui, X., Lüke, C., and Dumont, M. G. (2013). Aerobic methanotroph diversity in Riganqiao peatlands on the Qinghai-Tibetan plateau. Environ. Microbiol. Rep. 5, 566-574. doi: 10.1111/1758-2229.12046

Devries, G. E., Arfman, N., Terpstra, P., and Dijkhuizen, L. (1992). 
Cloning, expression, and sequence analysis of the Bacillus methanolicus $\mathrm{C} 1$ methanol dehydrogenase gene. J. Bacteriol. 174, 53465353.

de Zwart, J. M. M., Nelisse, P. N., and Kuenen, J. G. (1996). Isolation and characterization of Methylophaga sulfidovorans sp. nov.: an obligately methylotrophic, aerobic, dimethylsulfide oxidizing bacterium from microbial mat. FEMS Microbiol. Ecol. 20, 261270. doi: 10.1111/j.1574-6941.1996. tb00324.x

Ding, Y. H. R., Zhang, S. P., Tomb, J. F., and Ferry, J. G. (2002). Genomic and proteomic analyses reveal multiple homologs of genes encoding enzymes of the methanol: coenzyme $M$ methyltransferase system that are differentially expressed in methanoland acetate-grown Methanosarcina thermophila. FEMS Microbiol. Lett. 215, 127-132. doi: 10.1111/j.15746968.2002.tb11381.x

Dixon, J. L., Beale, R., and Nightingale, P. D. (2011). Microbial methanol uptake in northeast Atlantic waters. ISME J. 5, 704-716. doi: 10.1038/ismej.2010.169

Dixon, J. L., Sargeant, S., Nightingale, P. D., and Murrell, J. C. (2013). Gradients in microbial methanol uptake: productive coastal upwelling waters to oligotrophic gyres in the Atlantic Ocean. ISME J. 7, 568-580. doi: 10.1038/ismej. 2012.130

Doronina, N. V., Gogleva, A. A., and Trotsenko, Y. A. (2012). Methylophilus glucosoxydans sp nov., a restricted facultative methylotroph from rice rhizosphere. Int. J. Syst. Evol. Microbiol. 62, 196-201. doi: 10.1099/ijs.0.024620-0

Doronina, N. V., Kaparullina, E. N., Bykova, T. V., and Trotsenko, Y. A. (2013). Methylopila musalis sp. nov., a new aerobic facultatively methylotrophic bacterium isolated from banana fruit. Int. J. Syst. Evol. Microbiol. 63, 1847-1852. doi: 10.1099/ijs. 0.042028-0

Doronina, N. V., Kaparullina, E. N., and Trotsenko, Y. A. (2011). Methylovorus menthalis, a novel species of aerobic obligate methylobacteria associated with plants. Microbiology 80, 713-719. doi: 10.1134/S0026261711050043

Dörr, N., Glaser, B., and Kolb, S. (2010). Methanotrophic communities in Brazilian ferralsols from naturally forested, afforested, and agricultural sites. Appl. Environ. Microbiol. 76, 1307-1310. doi: 10.1128/AEM.02282-09
Drake, H. L., Gossner, A. S., and Daniel, S. L. (2008). Old acetogens, new light. Ann. N. Y. Acad. Sci. 1125, 100-128. doi: 10.1196/annals.1419.016

Drake, H. L., Horn, M. A., and Wust, P. K. (2009). Intermediary ecosystem metabolism as a main driver of methanogenesis in acidic wetland soil. Environ. Microbiol. Rep. 1, 307318. doi: 10.1111/j.1758-2229.2009. 00050.x

Dunfield, P. F. (2007). “The soil methane sink," in Green House Gas Sinks, eds D. S. Reay, C. N. Hewitt, K. A. Smith, and J. Grace (Wallingford: CABI), 152170. doi: 10.1079/9781845931896. 0152

Dunfield, P. F., Belova, S. E., Vorob'ev, A. V., Cornish, S. L., and Dedysh, S. N. (2010). Methylocapsa aurea sp. nov., a facultative methanotroph possessing a particulate methane monooxygenase, and emended description of the genus Methylocapsa. Int. J. Syst. Evol. Microbiol. 60, 2659-2664. doi: 10.1099/ijs.0.020149-0

Firsova, J., Doronina, N., Lang, E., Sproer, C., Vuilleumier, S. and Trotsenko, Y. (2009). Ancylobacter dichloromethanicus sp. nov. - a new aerobic facultatively methylotrophic bacterium utilizing dichloromethane. Syst. Appl. Microbiol. 32, 227-232. doi: 10.1016/j.syapm.2009.02.002

Fitriyanto, N. A., Fushimi, M., Matsunaga, M., Petriwinigrum, A. Iwama, T., and Kawai, K. (2011). Molecular structure and gene analysis of Ce3+-induced methanol dehydrogenase of Bradyrhizobium sp. MAFF 211645. J. Biosci. Bioeng. 111, 613-617. doi: 10.1016/j.jbiosc.2011.01.015

Forster, P., Ramaswamy, V., Artaxo, P., Berntsen, T., Betts, R., Fahey, D. W., et al. (2007). "Changes in atmospheric constituents and in radiative forcing," in Climate change 2007: The Physical Science Basis. Contribution of Working Group I to the Fourth Assessment Report of the Intergovernmental Panel on Climate Change, eds S. Solomon, D. Qin, M. Manning, Z. Chen, M. Marquis, K. B. Averyt, et al. (Cambridge: Cambridge University Press), 129-234.

Friedrich, M. W. (2002). Phylogenetic analysis reveals multiple lateral transfers of adenosine-5' phosphosulfate reductase genes among sulfate-reducing microorganisms. J. Bacteriol. 184, 278-289. doi 10.1128/JB.184.1.278-289.2002

Galbally, I. E., and Kirstine, W. (2002). The production of methanol by flowering plants and the global cycle of methanol. J. Atmos. Chem. 43,
195-229. doi: 10.1023/A:1020684 815474

Giovannoni, S. J., Hayakawa, D. H., Tripp, H. J., Stingl, U., Givan, S. A., Cho, J. C., et al. (2008). The small genome of an abundant coastal ocean methylotroph. Environ. Microbiol. 10, 1771-1782. doi: 10.1111/j.14622920.2008.01598.x

Gogleva, A. A., Kaparullina, E. N. Doronina, N. V., and Trotsenko, Y. A. (2010). Methylophilus flavus sp. nov. and Methylophilus luteus sp. nov., aerobic, methylotrophic bacteria associated with plants. Int. J. Syst. Evol. Microbiol. 60, 2623-2628. doi: 10.1099/ijs.0.019455-0

Gogleva, A. A., Kaparullina, E N., Doronina, N. V., and Trotsenko, Y. A. (2011). Methylobacillus arboreus sp nov., and Methylobacillus gramineus sp nov., novel nonpigmented obligately methylotrophic bacteria associated with plants. Syst. Appl. Microbiol. 34, 477-481. doi: 10.1016/j.syapm.2011.03.005

Gupta, V., Smemo, K. A., Yavitt, J. B., and Basiliko, N. (2012) Active methanotrophs in two contrasting North American peatland ecosystems revealed using DNA-SIP. Microb. Ecol. 63, 438-445. doi: 10.1007/s00248-011-9902-z

Gvozdev, A. R., Tukhvatullin, I. A., and Gvozdev, R. I. (2012). Quinone-dependent alcohol dehydrogenases and FAD-dependent alcohol oxidases. Biochemistry (Moscow) 77, 843-856. doi: $10.1134 / \mathrm{S} 0006297912080056$

Hagemeier, C. H., Kruer, M., Thauer, R. K., Warkentin, E., and Ermler, U. (2006). Insight into the mechanism of biological methanol activation based on the crystal structure of the methanol-cobalamin methyltransferase complex. Proc. Natl. Acad. Sci. U.S.A. 103, 18917-18922. doi 10.1073/pnas.0603650103

Halsey, K. H., Carter, A. E., and Giovannoni, S. J. (2012). Synergistic metabolism of a broad range of $\mathrm{Cl}$ compounds in the marine methylotrophic bacterium HTCC2181. Environ. Microbiol. 14, 630-640. doi: 10.1111/j.14622920.2011.02605.x

Hartner, F. S., and Glieder, A. (2006) Regulation of methanol utilisation pathway genes in yeasts. Microb. Cell Fact 5, 1-29. doi: 10.1186/1475 2859-5-39

He, R., Wooller, M. J., Pohlman, J. W., Quensen, J., Tiedje, J. M., and Leigh, M. B. (2012). Diversity of active aerobic methanotrophs along depth profiles of arctic and subarctic lake water column and sediments. ISME J. 6, 1937-1948. doi: 10.1038/ismej.2012.34

Heikes, B. G., Chang, W. N., Pilson, M. E. Q., Swift, E., Singh, H. B., Günther, A., et al. (2002). Atmospheric methanol budget and ocean implication. Glob. Biogeochem. Cycle 16, 1-30. doi: 10.1029/2002GB 001895

Hirayama, H., Suzuki, Y., Abe, M., Miyazaki, M., Makita, H., Inagaki, F., etal. (2011). Methylothermus subterraneus sp. nov., a moderately thermophilic methanotroph isolated from a terrestrial subsurface hot aquifer. Int. J. Syst. Evol. Microbiol. 61, 2646-2653. doi: 10.1099/ijs.0.028092-0

Holmes, A. J., Costello, A., Lidstrom, M. E., and Murrell, J. C. (1995). Evidence that particulate methane monooxygenase and ammonia monooxygenase may be evolutionarily related. FEMS Microbiol. Lett. 132, 203208. doi: 10.1111/j.1574-6968.1995. tb07834.x

Hoppe, T., Peters, K., and Schmidt, F. (2011). Methylobacterium bullatum sp. nov., a methylotrophic bacterium isolated from Funaria hygrometrica. Syst. Appl. Microbiol. 34, 482-486. doi: 10.1016/j.syapm.2010. 12.005

Idris, R., Kuffner, M., Bodrossy, L., Puschenreiter, M., Monchy, S., Wenzel, W. W., etal. (2006). Characterization of Ni-tolerant methylobacteria associated with the hyperaccumulating plant Thlaspi goesingense and description of Methylobacterium goesingense $\mathrm{sp}$ nov. Syst. Appl. Microbiol. 29, 634644. doi: 10.1016/j.syapm.2006. 01.011

Im, W. T., Aslam, Z., Lee, M., Ten, L. N., Yang, D. C., and Lee, S. T. (2006). Starkeya koreensis sp nov., isolated from rice straw. Int. J. Syst. Evol. Microbiol. 56, 2409-2414. doi: 10.1099/ijs.0.64093-0

Ito, T., Fujimura, S., Uchino, M., Tanaka, N., Matsufuji, Y., Miyaji, T., et al. (2007). Distribution, diversity and regulation of alcohol oxidase isozymes, and phylogenetic relationships of methylotrophic yeasts. Yeast 24, 523-532. doi: 10.1002/ yea. 1490

Jacob, D. J., Field, B. D., Li, Q. B., Blake, D. R., De Gouw, J., Warneke, C., et al. (2005). Global budget of methanol: constraints from atmospheric observations. J. Geophys. Res. Atmos. 110, D08303. doi: 10.1029/2004JD 005172

Jehmlich, N., Schmidt, F., Taubert, M., Seifert, J., Bastida, F., Von Bergen, M., et al. (2010). Protein-based stable 
isotope probing. Nat. Protoc. 5, 1957 1966. doi: 10.1038/nprot.2010.166

Kalyuzhnaya, M. G., Beck, D. A. C., Vorobev, A., Smalley, N., Kunkel, D. D., Lidstrom, M. E., et al. (2012). Novel methylotrophic isolates from lake sediment, description of Methylotenera versatilis sp. nov. and emended description of the genus Methylotenera. Int. J. Syst. Evol. Microbiol. 62, 106-111. doi: 10.1099/ijs.0.029165-0

Kalyuzhnaya, M. G., and Chistoserdova, L. (2005). Community-level analysis: genes encoding methanopterindependent enzymes. Environ. Microbiol. 397, 443-454. doi: 10.1016/ S0076-6879(05)97027-4

Kalyuzhnaya, M. G., Hristova, K. R., Lidstrom, M. E., and Chistoserdova, L. (2008). Characterization of a novel methanol dehydrogenase in representatives of Burkholderiales: implications for environmental detection of methylotrophy and evidence for convergent evolution. J. Bacteriol. 190, 3817-3823. doi: 10.1128/ JB.00180-08

Kalyuzhnaya, M. G., Khmelenina, V. N., Kotelnikova, S., Holmquist, L., Pedersen, K., and Trotsenko, Y. A. (1999). Methylomonas scandinavica sp nov., a new methanotrophic psychrotrophic bacterium isolated from deep igneous rock ground water of Sweden. Syst. Appl. Microbiol. 22, 565572. doi: 10.1016/S0723-2020(99) 80010-1

Kalyuzhnaya, M. G., Lidstrom, M. E., and Chistoserdova, L. (2004). Utility of environmental primers targeting ancient enzymes: methylotroph detection in Lake Washington. Microb. Ecol. 48, 463-472. doi: 10.1007/s00248-0040212-6

Keppler, F., Hamilton, J. T. G., Brass, M., and Rockmann, T. (2006). Methane emissions from terrestrial plants under aerobic conditions. Nature 439, 187-191. doi: 10.1038 /nature04420

Keppler, F., Harper, D. B., Rockmann, T., Moore, R. M., and Hamilton, J. T. G. (2005). New insight into the atmospheric chloromethane budget gained using stable carbon isotope ratios. Atmos. Chem. Phys. 5, 2403-2411. doi: 10.5194/acp-52403-2005

Kim, T. G., Lee, E.-H., and Cho, K.-S. (2013). Effects of nonmethane volatile organic compounds on microbial community of methanotrophic biofilter. Environ. Biotechnol. 97, 6549-6559. doi: 10.1007/s00253-012-4443-Z
Kip, N., Dutilh, B. E., Pan, Y., Bodrossy, L., Neveling, K., Kwint, M. P., et al. (2011). Ultra-deep pyrosequencing of pmoA amplicons confirms the prevalence of Methylomonas and Methylocystis in Sphagnum mosses from a Dutch peat bog. Environ. Microbiol. Rep. 3, 667673. doi: 10.1111/j.1758-2229.2011. 00260.x

Kist, J., and Tate, R. L. (2013a). Phylogeny of bacterial methylotrophy genes reveals robustness in Methylobacterium mxaF sequences and mxa operon structure. Soil Biol. Biochem. 58, 49-57. doi: 10.1016/j.soilbio.2012.12.010

Kist, J., and Tate, R. L. (2013b). Application of mxaF functional gene sequence to determine genetic relatedness among environmental Methylobacterium strains (PPFMs). Soil Biol. Biochem. 58, 313-322. doi: 10.1016/j.soilbio.2012.12.009

Knief, C., Delmotte, N., Chaffron, S. Stark, M., Innerebner, G., Wassmann, R., Von Mering, C., and Vorholt, J. A. (2012a). Metaproteogenomic analysis of microbial communities in the phyllosphere and rhizosphere of rice. ISME J. 6, 1378-1390. doi: 10.1038/ismej.2011.192

Knief, C., Dengler, V., Bodelier, P. L. E., and Vorholt, J. A. (2012b). Characterization of Methylobacterium strains isolated from the phyllosphere and description of Methylobacterium longum sp. nov. Ant.Van Leeuwenhoek. Int. J. Gen. Mol. Microbiol. 101, 169-183. doi: 10.1007/s10482-011-9650-6

Knief, C., Frances, L., Cantet, F., and Vorholt, J. A. (2008). Cultivation-independent characterization of Methylobacterium populations in the plant phyllosphere by automated ribosomal intergenic spacer analysis. Appl. Environ. Microbiol. 74, 2218-2228. doi: 10.1128/AEM.02532-07

Knief, C., Frances, L., and Vorholt, J. A. (2010a). Competitiveness of diverse Methylobacterium strains in the phyllosphere of Arabidopsis thaliana and identification of representative models, including $M$. extorquens PA1. Microb. Ecol. 60, 440-452. doi: 10.1007/s00248-010-9725-3

Knief, C., Ramette, A., Frances, L., Alonso-Blanco, C., and Vorholt, J. A. (2010b). Site and plant species are important determinants of the Methylobacterium community composition in the plant phyllosphere. ISME J. 4, 719-728. doi: 10.1038/ismej.2010.9

Kolb, S. (2009a). Aerobic methanoloxidizing bacteria in soil. FEMS
Microbiol. Lett. 300, 1-10. doi 10.1111/j.1574-6968.2009.01681.x

Kolb, S. (2009b). The quest for atmospheric methane oxidizers in forest soils. Environ. Microbiol. Rep. 1, 336-346. doi: 10.1111/j.17582229.2009.00047.x

Krog, A., Heggeset, T. M. B., Muller, J. E. N., Kupper, C. E., Schneider, O., Vorholt, J. A., et al. (2013). Methylotrophic Bacillus methanolicus encodes two chromosomal and one plasmid born $\mathrm{NAD}(+)$-dependent methanol dehydrogenase paralogs with different catalytic and biochemical properties. PLoS ONE 8:e59188. doi: 10.1371/journal.pone. 0059188

Lang, E., Swiderski, J., Stackebrandt, E., Schumann, P., Sproer, C. and Sahin, N. (2008). Description of Ancylobacter oerskovii sp. nov. and two additional strains of Ancylobacter polymorphus. Int. J. Syst. Evol. Microbiol. 58, 1997-2002. doi: 10.1099/ijs.0.65666-0

Lau, E., Fisher, M. C., Steudler, P. A., and Cavanaugh, C. M. (2013). The methanol dehydrogenase gene, mxaF, as a func tional and phylogenetic marker for proteobacterial methanotrophs in natural environments. PLOS ONE 8:e56993. doi: 10.1371/journal.pone. 0056993

Lavalleur, H. J., and Colwell, F. S. (2013). Microbial characterization of basalt formation waters targeted for geological carbon sequestration. FEMS Microbiol. Ecol. 85, 62-73. doi: 10.1111/1574-6941.12098

Li, L., Zheng, J. W., Hang, B. J., Doronina, N. V., Trotsenko, Y. A., He, J., et al. (2011). Methylopila jiangsuensis sp. nov., an aerobic, facultatively methylotrophic bacterium. Int. J. Syst. Evol. Microbiol. 61, 1561-1566. doi: 10.1099/ijs.0.020925-0

Ling, J. Y., Zhang, G. Y., Sun, H. B., Fan, Y. Y., Ju, J. H., and Zhang, C. K. (2011). Isolation and characterization of a novel pyrenedegrading Bacillus vallismortis strain JY3A. Sci. Tot. Environ. 409, 1994 2000. doi: 10.1016/j.scitotenv.2011. 02.020

Liu, L., Li, Y. H., Li, S. L., Hu, N., He Y. M., Pong, R., et al. (2012). Comparison of next-generation sequencing systems. J. Biomed. Biotechnol. 2012, 251364. doi: 10.1155/2012/ 251364

Lu, H. J., Kalyuzhnaya, M., and Chandran, K. (2012). Comparative proteomic analysis reveals insights into anoxic growth of Methyloversatilis universalis FAM5 on methanol and ethanol. Environ. Microbiol.
14, 2935-2945. doi: 10.1111/j.1462 2920.2012.02857.x

Lüke, C., and Frenzel, P. (2011). Potential of pmoA amplicon pyrosequencing for methanotroph diversity studies. Appl. Environ. Microbiol. 77, 6305-6309. doi: 10.1128/AEM.05355-11

Lüke, C., Krause, S., Cavigiolo, S., Greppi, D., Lupotto, E., and Frenzel, P. (2010). Biogeography of wetland rice methanotrophs. Environ. Microbiol. 12, 862-872. doi: 10.1111/j.1462-2920. 2009.02131.x

Madhaiyan, M., Poonguzhali, S., Kwon, S. W., and Sa, T. M. (2009a). Methylobacterium phyllosphaerae sp. nov., a pink-pigmented, facultative methylotroph from the phyllosphere of rice. Int. J. Syst. Evol. Microbiol. 59, 22-27. doi: 10.1099/ijs.0. 001693-0

Madhaiyan, M., Poonguzhali, S., Kwon, S. W., and Sa, T. M. (2009b). Methylophilus rhizosphaerae sp. nov., a restricted facultative methylotroph isolated from rice rhizosphere soil. Int. J. Syst. Evol. Microbiol. 59, 2904-2908. doi: 10.1099/ijs.0. 009811-0

Madhaiyan, M., Poonguzhali, S., Senthilkumar, M., Lee, J. S., and Lee, K. C. (2012). Methylobacterium gossipiicola sp. nov., a pink-pigmented, facultatively methylotrophic bacterium isolated from the cotton phyllosphere. Int. J. Syst. Evol. Microbiol. 62, 162-167. doi: 10.1099/ijs.0.030148-0

McDonald, I. R., and Murrell, J. C. (1997). The methanol dehydrogenase structural gene mxaF and its use as a functional gene probe for methanotrophs and methylotrophs. Appl. Environ. Microbiol. 63, 32183224.

Moosvi, S. A., Pacheco, C. C., Mcdonald, I. R., De Marco, P., Pearce, D. A., Kelly, D. P., et al. (2005). Isolation and properties of methanesulfonatedegrading Afipia felis from Antarctica and comparison with other strains of A. felis. Environ. Microbiol. 7, 22-33. doi: 10.1111/j.14622920.2004.00661.x

Mustakhimov, I., Kalyuzhnaya, M. G., Lidstrom, M. E., and Chistoserdova, L. (2013). Insights into denitrification in Methylotenera mobilis from denitrification pathway and methanol metabolism mutants. J. Bacteriol. 195, 2207-2211. doi: 10.1128/JB.00069-13

Nakagawa, T., Inagaki, A., Ito, T., Fujimura, S., Miyaji, T., Yurimoto, H., et al. (2006). Regulation of two distinct alcohol oxidase promoters 
in the methylotrophic yeast Pichia methanolica. Yeast 23, 15-22. doi: 10.1002/yea. 1334

Nakagawa, T., Mitsui, R., Tani, A., Sasa, K., Tashiro, S., Iwama, T., etal. (2012). A catalytic role of XoxF1 as La3+-dependent methanol dehydrogenase in Methylobacterium extorquens strain AM1. PLoS ONE 7:e50480. doi: 10.1371/journal.pone. 0050480

Nakagawa, T., Uchimura, T., and Komagata, K. (1996). Isozymes of methanol oxidase in a methanolutilizing yeast, Pichia methanolica IAM 12901. J. Ferment. Bioeng. 81, 498-503. doi: 10.1016/0922338X(96)81469-3

Nebel, M. E., Wild, S., Holzhauser, M., Huttenberger, L., Reitzig, R., Sperber, M., et al. (2011). Jaguc - a software package for environmental diversity analyses. J. Bioinform. Comput. Biol. 9, 749-773. doi: 10.1142/S0219720011005781

Neufeld, J. D., Schäfer, H., Cox, M. J., Boden, R., Mcdonald, I. R., and Murrell, J. C. (2007). Stable-isotope probing implicates Methylophaga spp and novel Gammaproteobacteria in marine methanol and methylamine metabolism. ISME J. 1, 480-491. doi: 10.1038/ismej.2007.65

Nozaki, M., Suzuki, N., and Washizu, Y. (1996). "Microbial oxidation of alcohols by Candida boidinii: selective oxidation," in ACS Symposium Series. Biotechnology for Improved Foods and Flavors, Vol. 637, eds G. R. Takeoka, R. Teranishi, P. J. Williams, and A. Kobayashi (Washington, DC: American Chemical Society), 188-195.

Ogiso, T., Ueno, C., Dianou, D., Huy, T. V., Katayama, A., Kimura, M., and Asakawa, S. (2012). Methylomonas koyamae sp. nov., a type I methaneoxidizing bacterium from floodwater of a rice paddy field. Int. Syst. Evol. Microbiol. 62, 1832-1837. doi: 10.1099/ijs.0.035261-0

Op den Camp, H. J. M., Islam, T., Stott, M. B., Harhangi, H. R., Hynes, A., Schouten, S., et al. (2009). Environmental, genomic and taxonomic perspectives on methanotrophic Verrucomicrobia. Environ. Microbiol. Rep. 1, 293-306. doi: 10.1111/j.17582229.2009.00022.x

Ozimek, P., Veenhuis, M., and Van Der Klei, I. J. (2005). Alcohol oxidase: a complex peroxisomal, oligomeric flavoprotein. FEMS Yeast Res. 5, 975-983. doi: 10.1016/j.femsyr.2005. 06.005

Park, H., Lee, H., Ro, Y. T., and Kim, Y. M. (2010). Identification and functional characterization of a gene for the methanol: $N, N^{\prime}$-dimethyl-4nitrosoaniline oxidoreductase from Mycobacterium sp. strain JC1 (DSM 3803). Microbiology 156, 463-471. doi: 10.1099/mic.0.034124-0

Penger, J., Conrad, R., and Blaser, M. (2012). Stable carbon isotope fractionation by methylotrophic methanogenic Archaea. Appl. Environ. Microbiol. 78, 7596-7602. doi: 10.1128/AEM.01773-12

Pilloni, G., Granitsiotis, M. S., Engel, M., and Lüders, T. (2012). Testing the limits of 454 pyrotag sequencing: reproducibility, quantitative assessment and comparison to T-RFLP fingerprinting of aquifer microbes. PLoS ONE 7:e40467. doi: 10.1371/journal.pone.0040467

Quince, C., Lanzen, A., Davenport, R. J., and Turnbaugh, P. J. (2011). Removing noise from pyrosequenced amplicons. BMC Bioinform. 12:38. doi: 10.1186/1471-2105$12-38$

Reid, M. F., and Fewson, C. A. (1994). Molecular characterization of microbial alcohol dehydrogenases. Crit. Rev. Microbiol. 20, 13-56. doi: 10.3109/104084194091 13545

Ronaghi, M., Uhlen, M., and Nyren, P. (1998). A sequencing method based on real-time pyrophosphate. Science 281, 363-367. doi: 10.1126/science.281.5375.363

Rosen, M. J., Callahan, B. J., Fisher, D. S., and Holmes, S. P. (2012). Denoising PCR-amplified metagenome data. BMC Bioinform. 13:283. doi: 10.1186/1471-2105 13-283

Saidi-Mehrabad, A., He, Z. G., Tamas, I., Sharp, C. E., Brady, A. L., Rochman, F. F., et al. (2013). Methanotrophic bacteria in oilsands tailings ponds of northern Alberta. ISME J. 7, 908-921. doi: 10.1038/ismej. 2012.163

Schauer, S., Kämpfer, P., Wellner, S., Sproer, C., and Kutschera, U. (2011). Methylobacterium marchantiae sp. nov., a pink-pigmented, facultatively methylotrophic bacterium isolated from the thallus of a liverwort. Int. J. Syst. Evol. Microbiol. 61, 870-876. doi: 10.1099/ijs.0. 021915-0

Schmidt, S., Christen, P., Kiefer, P., and Vorholt, J. A. (2010). Functional investigation of methanol dehydrogenase-like protein XoxF in Methylobacterium extorquens AM1. Microbiology 156, 2575-2586. doi: 10.1099/mic.0.038570-0

Shrestha, P. M., Kammann, C., Lenhart, K., Dam, B., and Liesack, W. (2012). Linking activity, composition and seasonal dynamics of atmospheric methane oxidizers in a meadow soil. ISME J. 6, 1115-1126. doi: 10.1038/ismej.2011.179

Silva, V. C., Peres, M. F. S., and Gattas, E. A. L. (2009). Application of methylotrophic yeast Pichia pastoris in the field of food industry - a review. $J$. Food Agric. Environ. 7, 268-273.

Sipiczki, M. (2012). Candida borneonana sp nov., a methanolassimilating anamorphic yeast isolated from decaying fruit. Int. J. Syst. Evol. Microbiol. 62, 2303-2306. doi: 10.1099/ijs.0. 039412-0

Skovran, E., Palmer, A. D., Rountree, A. M., Good, N. M., and Lidstrom, M. E. (2011). XoxF is required for expression of methanol dehydrogenase in Methylobacterium extorquens AM1. J. Bacteriol. 193, 6032-6038. doi: 10.1128/JB 05367-11

Stacheter, A., Noll, M., Lee, C. K., Selzer, M., Glowik, B., Ebertsch, L., et al. (2013). Methanol oxidation by temperate soils and environmental determinants of associated methylotrophs. ISME J. 7, 1051-1064. doi: 10.1038/ismej. 2012.167

Tani, A., Sahin, N., and Kimbara, K. (2012a). Methylobacterium gnaphalii sp. nov., isolated from leaves of Gnaphalium spicatum. Int. J. Syst. Evol. Microbiol. 62, 2602-2607. doi: 10.1099/ijs.0. 037713-0

Tani, A., Sahin, N., and Kimbara, K. (2012b). Methylobacterium oxalidis sp. nov., isolated from leaves of Oxalis cornic ulata. Int. J. Syst. Evol. Microbiol. 62, 1647-1652. doi: 10.1099/ijs.0. 033019-0

Thauer, R. K. (1998). Biochemistry of methanogenesis: a tribute to Marjory Stephenson. Microbiology 144, 2377-2406. doi: 10.1099/00221287 144-9-2377

Trotsenko, Y. A., and Bystrykh, L. V. (1990). Production of metabolites by methylotrophic Yeasts. Biotechnol. Adv. 8, 105-119. doi: 10.1016/07349750(90)90007-X

Vandenbosch, H., Schutgens, R. B. H., Wanders, R. J. A., and Tager, J. M. (1992). Biochemistry of peroxisomes. Annu. Rev. Biochem. 61, 157-197. doi: 10.1146/ annurev.bi.61.070192.001105

Vanophem, P. W., Vanbeeumen, J., and Duine, J. A. (1993). Nicotinoprotein $[\mathrm{Nad}(\mathrm{P})$-Containing] alcohol aldehyde oxidoreductases - purification and characterization of a novel type from Amycolatopsis methanolica. Eur. J. Biochem. 212, 819-826. doi: 10.1111/j.1432-1033. 1993.tb17723.x

Vorholt, J. A. (2012). Microbial life in the phyllosphere. Nat. Rev. Microbiol. 10, 828-840. doi: 10.1038/nrmicro2910

Vorholt, J. A., Chistoserdova, L., Stolyar, S. M., Thauer, R. K., and Lidstrom, M. E. (1999). Distribution of tetrahydromethanopterin-dependent enzymes in methylotrophic bacteria and phylogeny of methenyl tetrahydromethanopterin cyclohydrolases. J. Bacteriol. 181, 57505757.

Vorobev, A. V., Baani, M., Doronina, N. V., Brady, A. L., Liesack, W., Dunfield, P. F., et al. (2011). Methyloferula stellata gen. nov., sp nov., an acidophilic, obligately methanotrophic bacterium that possesses only a soluble methane monooxygenase. Int. J. Syst. Evol. Microbiol. 61, 2456-2463. doi: 10.1099/ijs.0. 028118-0

Wellner, S., Lodders, N., and Kämpfer, P. (2012). Methylobacterium cerastii sp nov., isolated from the leaf surface of Cerastium holosteoides. Int. J. Syst. Evol. Microbiol. 62, 917-924. doi: 10.1099/ijs.0.03 0767-0

Wieczorek, A. S., Drake, H. L., and Kolb, S. (2011). Organic acids and ethanol inhibit the oxidation of methane by mire methanotrophs. FEMS Microbiol. Ecol. 77, 2839. doi: 10.1111/j.1574-6941.2011. 01080.x

Wilson, S. M., Gleisten, M. P., and Donohue, T. J. (2008). Identification of proteins involved in formaldehyde metabolism by Rhodobacter sphaeroides. Microbiology 154, 296-305. doi: 10.1099/mic.0. 2007/011346-0

Xin, Y. H., Zhou, Y. G., and Chen, W. X. (2006). Ancylobacter polymorphus sp. nov. and Ancylobacter vacuolatus sp. nov. Int. J. Syst. Evol. Microbiol. 56, 1185-1188. doi: 10.1099/ijs.0. 64118-0

Xin, Y. H., Zhou, Y. G., Zhou, H. L., and Chen, W. X. (2004). Ancylobacter rudongensis sp nov., isolated from roots of Spartina anglica. Int. J. Syst. Evol. Microbiol.54, 385-388. doi: 10.1099/ijs.0. 02466-0

Zhou, W. H., Das, A., Habel, J. E., Liu, Z. J., Chang, J., Chen, L. R., et al. (2005). Isolation, crystallization and preliminary X-ray analysis of a methanol-induced corrinoid protein from Moorella thermoacetica. Acta Crystallogr. Sect. F Struct. Biol. Cryst. Commun. 61, 
537-540. doi: $10.1107 /$ S1744309105 010511

Conflict of Interest Statement: The authors declare that the research was conducted in the absence of any commercial or financial relationships that could be construed as a potential conflict of interest.
Received: 19 July 2013; accepted: 19 August 2013; published online: 05 September 2013.

Citation: Kolb S and Stacheter A (2013) Prerequisites for amplicon pyrosequencing of microbial methanol utilizers in the environment. Front. Microbiol. 4:268. doi: 10.3389/fmicb.2013.00268
This article was submitted to Terrestrial Microbiology, a section of the journal Frontiers in Microbiology.

Copyright (C) 2013 Kolb and Stacheter. This is an open-access article distributed under the terms of the Creative Commons Attribution License (CC BY). The use, distribution or reproduction in other forums is permitted, provided the original author(s) or licensor are credited and that the original publication in this journal is cited, in accordance with accepted academic practice. No use, distribution or reproduction is permitted which does not comply with these terms. 